\title{
Kentsel Yayılma Alanları ve Bu Alanlardaki Konut Talebi Üzerine Nitel Bir Araştırma*
}

\author{
Gizem Hayrullahoğlu ${ }^{1}$ \\ ORCID: 0000-0002-3867-193X
}

*

\author{
Yeşim Aliefendioğlu Tanrıvermiş² \\ ORCID: 0000-0002-0859-7150
}

\author{
Harun Tanrivermiş ${ }^{3}$ \\ ORCID: 0000-0002-0765-5347
}

Öz

Bir tür kentsel gelişim morfolojisini betimleyen kentsel yayllma, dünya kentlerinin sürdürülebilirliği ile ilgili endişe verici sorun alanlarndan biri olup, Türkiye'deki büyükşehirlerin de bu sorunla yüzleştiği görülmektedir. Politika yapıcıların farkında olmadan yayılmayı teşvik eden düzenlemeler yapması kentin çeperlerinde yeni yaşama mekânlarının oluşma eğilimini artırmakta ve düzensiz kentsel büyümeye yol açmaktadır. Kontrollü kentsel büyüme, doğal kaynakların yanı sıra finansal kaynakların da en etkin kullanımın vurgulamakta olup, kentlerin denetimsiz genişlemesi yerel yönetimlerce să̆lanan hizmetlerin mali yükünü artırmaktadır. Kentsel yayılmanın çeperlerde yer alan bölgelerde yeni yaşam alanları kurulması ile ilişkili olduğu varsayıldığında, çeperlerdeki konut arz ve talep göstergelerini kontrollü kentsel büyümeyi başarmak için göz önünde bulundurulması gereken faktörler arasında göstermek mümkündür. Bu nitel araştırmada kentsel yayılma alanları ve bu alanlardaki konut talebine etki eden sosyoekonomik ve mekânsal faktörler ele alınmıştır. Dünyadaki eğilimler, kontrollü bir kentsel büyüme için politika yapıcıların müdahaleci olmak yerine yönlendirici bir rol üstlenmeleri gerektiğini ortaya koymaktadır. Bu bă̆lamda, kentsel büyüme eğilimini ölçmek ve kontrolsüz büyümeye daha etkin müdahale edebilmek için kentsel yayılma alanlarında kent merkezinden farklılaşan konut dinamiklerinin ve bu alanlardaki konut talebine ilişin varsayımların dikkate alınması gerektiği sonucuna varılmaktadır.

Anahtar Kelimeler: Kentsel yayılma, kentsel büyüme, konut talebi.

\footnotetext{
* Bu makale, Gizem Hayrullahoğlu tarafından Doç. Dr. Yeşim Aliefendioğlu Tanrıvermiş danışmanlığında tamamlanan yüksek lisans tez çalışmasından üretilmiştir.

${ }^{1}$ Doktora Öğrencisi, Gazi Üniversitesi, E-mail: gizemhayrullahoglu@gmail.com

2 Doç. Dr., Ankara Üniversitesi, E-mail: aliefendioglu@ankara.edu.tr

${ }^{3}$ Prof. Dr., Ankara Üniversitesi, E-mail: tanrivermis@ankara.edu.tr

idealkent @ Kent Araştırmaları Dergisi (Journal of Urban Studies)

http://idealkentdergisi.com

Geliş Tarihi Received Date: 02.02.2021 Kabul Tarihi Accepted Date: 27.12.2021
} 


\title{
A Qualitative Research on Urban Sprawl Areas and Housing Demand in These Areas*
}

\author{
Gizem Hayrullahoğlu1 ${ }^{1}$ \\ ORCID: 0000-0002-3867-193X
}

*

\author{
Yeşim Aliefendioğlu Tanrıvermiş² \\ ORCID: 0000-0002-0859-7150
}

\author{
Harun Tanrivermiş ${ }^{3}$ \\ ORCID: 0000-0002-0765-5347
}

\begin{abstract}
Urban sprawl, describing a kind of urban form, is a challenge for global cities dealing with sustainability, and Turkish metropolitan cities are also faced with this issue. Policymakers unwittingly make regulations that encourage expansion, which causes the formation of new settlements on the periphery and results in disordered urban growth. Controlled urban growth underlines the most efficient use of financial resources as much as natural resources, and ungoverned expansion increases the financial burden of local government services. Considering that expansion is related to the establishment of new settlements in the periphery, housing supply and demand indicators in sprawling areas become among the factors to be considered in order to achieve controlled urban growth. In this qualitative research, urban sprawl areas and socioeconomic and spatial factors affecting housing demand in there are discussed. Global trends reveal that policymakers should play a leading role instead of interfering to control urban growth. In this context, it is concluded that the housing dynamics in urban sprawl areas that differ from the city center and assumptions about housing demand in these areas should be taken into account in order to determine the urban growth trend and intervene more effectively on uncontrolled growth.
\end{abstract}

Keywords: Urban sprawl, urban growth, housing demand.

\footnotetext{
* This article is derived from the master's thesis prepared by Gizem Hayrullahoğlu under the supervision of Yeşim Aliefendioğlu Tanrıvermiş.

${ }^{1}$ PhD Candidate, Gazi University, E-mail: gizemhayrullahoglu@gmail.com

2 Assoc. Prof., Ankara University, E-mail: aliefendioglu@ankara.edu.tr

${ }^{3}$ Prof., Ankara University, E-mail: tanrivermis@ankara.edu.tr

idealkent @ Kent Araştırmaları Dergisi (Journal of Urban Studies)

http://idealkentdergisi.com

Geliş Tarihi Received Date: 02.02.2021 Kabul Tarihi Accepted Date: 27.12.2021
} 


\section{Giriş}

Geçtiğimiz on yıl içinde kentleşme düzeyi yüksek ülkelerin sayısı önemli ölçüde artmıştır. Birleşmiş Milletler (UN), tarihte ilk kez 2007 yılında kent nüfusunun küresel ölçekte kırsal nüfusu geride bıraktığını, 2018 yılında dünya nüfusunun \%55'inin kentlerde yaşadığını belirtmiştir (UN, 2019, s.11). UN, kentleşme eğiliminin artmaya devam edeceğini ve 2030 yılına kadar bu oranın \%60' bulacağını tahmin etmektedir (UN, 2019, s.55). Kentsel nüfus artış1nın bir sonucu olarak yeni kentsel mekânların geliştirilmesine gereksinim olmakta, ancak bu gereksinimi karşılayacak uygun arazi temin edilmediği durumda kentler düzensiz büyümekte ve çeperlere doğru yayılarak genişlemektedir (Travisi ve Camagni, 2005, s.1). Kentsel yayılma olarak kavramsallaştırılan bu olgu, sürdürülebilir kalkınma üzerindeki olumsuz etkileri nedeniyle 21'inci yüzyıl kentlerinin en çok tartışlan sorunlarından biri olarak görülmektedir (Martine, McGranahan, Montgomery, ve Fernandez-Castilla, 2008, s.2).

Ekonomik ve doğal kaynaklara olan talebin artması nedeniyle 20'nci yüzyıl sonlarına doğru kentsel yayılma üzerine yapılmış araştırmalara daha sık rastlanmakla birlikte, kavramın ilk olarak 1920'lerde Amerika Birleşik Devletleri (ABD)'nde yapılmış metropoliten planlarda kentsel bir problem olarak ele alındığı görülmektedir (Burchell vd., 1997, s.9). Kavramı akademik olarak ilk Buttenheim ve Cornick (1938) kullanmış, Avrupa ve ABD'deki metropollerin kırsal bölgelere doğru yayılarak genişlediğine vurgu yapmıştır (Buttenheim ve Cornick,1938, s.256). İkinci Dünya Savaşı öncesinde sermaye birikiminin artması kentsel yayılmayı tetiklemişse de kentlerin tarihsel gelişim süreci üzerine yapılan araştırmalar kentsel yayılmanın savaş sonrası ivme yakaladığını ortaya koymaktadır (Christiansen ve Loftsgarden, 2011, s.4; Gonzalez, 2009, s.42). Özellikle kent içindeki ulaşım teknolojileri ve araçlarının çeşitlilik kazanması kent merkezi ile çeper arasındaki etkileşimi artırmış ve yaşam mekânı ile ekonomik faaliyetlerin ayrılmasını sağlamıştır. Buna karşın kentsel sınırlar genişledikçe ulaşım, temizlik ve altyapı gibi kentsel hizmetlerin etkin sunumu ve yönetimi güçleşmiştir (Keleş, 2015, s.55).

Kentlerin sunduğu firsatların çekiciliği geçmişten bu yana savunulsa da son yirmi yıldır kent merkezlerinin itici gücü olduğu da tartışılmaktadır. Sözgelimi, beklentilere uygun konut arzının kent merkezlerinde karşılanamayışı bireylerin merkezden dışarıya doğru hareket etmesine neden olabilmektedir (Ewing, 1997, s.111). İklim değişikliği, doğal afet ve salgin gibi beklenmedik riskler nedeniyle ilave kentsel mekân talebi olabilmekte ya da nüfus yoğunluğu düşük olan bölgeler cazip gelebilmektedir. Modern toplumun değer, 
beklenti ve tüketim kalıplarını yansıtan yaşam tarzlarıyla ilişkili bu tür toplumsal süreçlerin kentlerin yayılarak büyümesinde büyük rol oynadığı görülmektedir. $\mathrm{Bu}$ anlamda yayılma alanlarının çekici gücü ve kent merkezlerinin itici gücü, kontrollü kentsel büyümeyi başarmak için göz önünde bulundurulması gereken faktörler olarak dikkati çekmektedir. Söz konusu güçleri açıklamak için faydalanılacak temel araçlardan biri ise yerleşim yerlerinin iç yapısını anlamaya olanak tanıyan konut piyasasıdır (Blumenfeld, 1949, s.54; Karantonis, 2008, s.2; Mieszkowski ve Mills, 1993, s.136). Konut piyasasında talep yapısı değiştikçe bu yapıya uyum sağlamak üzere kent çeperlerinde yeni konut arzı oluşturularak arz ve talep dengesi sağlanmaya çalışılmakta; böylece mekânsal planlamanın ötesinde, insan eylemlerinin bir sonucu olarak kentlerin dağını ve düşük yoğunluklu geliştiği bir yerleşim dokusu meydana gelmektedir. Bu çerçevede çalışmada sosyoekonomik ve mekânsal faktörlerin konut talebine etkisinin incelenmesiyle kontrollü mekânsal büyümeye girdi sağlamanın mümkün olup olmadığı araştırılmaktadır.

Çalışmada kentsel yayılma alanları ve bu alanlardaki konut talebini ele alan akademik araştırmaların geniş kapsamda incelendiği nitel bir süreç izlenmiştir. Kentsel yayılma olgusu, nedenleri ve etkileri disiplinler arası çalışmalar üzerinden tartışılmış ve kentsel yayılma alanlarındaki konut talebi sosyoekonomik ve mekânsal göstergeler çerçevesinde değerlendirilmiştir. Temel olarak kentsel yayılma kavramını kapsamın ortaya koymak, bireyleri kent çeperinde yaşamaya iten nedenleri araştırmak ve çeperlerdeki bağlam bağımlı olmayan konut talep belirleyicileri üzerinden kontrollü mekânsal büyüme stratejilerine girdi sağlamak hedeflenmiştir. Çalışmada kır-kent saçak bölgelerindeki konut talebi mekanizmalarını araştırmanın kentsel yayılmayı anlama ve kontrollü kentsel büyümeyi sağlamadaki rolü sorgulanmaktadır.

\section{Kentsel Yayılma Alanları}

Kentsel yayılma alanlarına odaklanan bu bölüme başlarken yayılmanın kentsel büyüme formu olduğu ve kentsel büyüme ve gelişme kavramlarından farklı anlam taşıdığı vurgulanmalıdır. Kentsel büyüme kent genelinde fiziksel değişimle birlikte kentsel alanın genişlemesi iken, kentsel gelişme kent yerleşimlerinin sosyal, kültürel, ekonomik ve fiziksel bileşenleriyle niteliksel olarak ileriye taşınmasıyla ilgilidir (Delibay, 2014, s.8). Kentler planlanandan farklı olarak saçaklara doğru büyüdüğünde istenmeyen bir fiziksel doku oluşmakta, bu doku ise kentsel yayılmayı karakterize etmektedir.

Kentsel yayılma alanları söz konusu olduğunda, kır ve kent arasındaki geçiş bölgesini özel olarak ele almak gerekmektedir. Kır-kent saçağı (RUF, 
rural-urban fringe) olarak adlandırılan bu kuşağ oluşturan ana kentsel karakterler kentsel yayılma olgusunu anlamayı kolaylaştırmaktadır (Harvey ve Clark, 1965, s.1). Tarım arazisi ve kentsel kullanımın bir arada olduğu bu bölgede kır ve kent çatışma halindedir. Tarımsal açıdan verimli arazilerin havaalanı, büyük sanayi alanları gibi kentsel kullanımlara ayrılması, orman arazisine yapılan golf sahası bu çatışmalara örnek verilebilir. Saçaklar kentin en kritik bölgelerinden biri olarak görülmekte ve yetkililerin bu bölgelere yönelik politika tutumları büyük önem taşımaktadır ( $\mathrm{Li}$, Qiu, Li, ve Xu, 2018, s.1). Dünyada saçak bölgelerinin öneminin farkında olan kent yönetimleri bu bölgelerde arazi gelişimini koordine etmek için yönetişim odaklı stratejiler geliştirmektedir (Scott vd., 2013, s.36-45).

Kentin önceden planlanmış bir sınırın ötesinde, kır-kent saçağına doğru düşük yoğunluklu olarak genişlemesi kentsel yayılma olarak ifade edilmektedir (Blumendfeld, 1949, s.62). Burada söz konusu olan yeterince iyi yönetilememiş ve düzene aykırı bir kentsel gelişme ve bundan kaynaklanan bir genişlemedir. Kırsal alanların zamanından önce ve plansız olarak kentsel kullanımlara dönüştürüldüğü bu alanlarda hâkim arazi kullanımlarıyla uyumsuz bir doku görülmektedir (Davidson ve Dolnick, 2004, s.384). Kırsal alan özelliğini yitirmiş, kentsel alan özelliğine ise tam anlamıla sahip olamayan düşük yoğunluklu yerleşimler kentsel yayılma alanlarının ayırt edici özelliğidir (Kanbak, 2013, s.14) (Şekil 1).

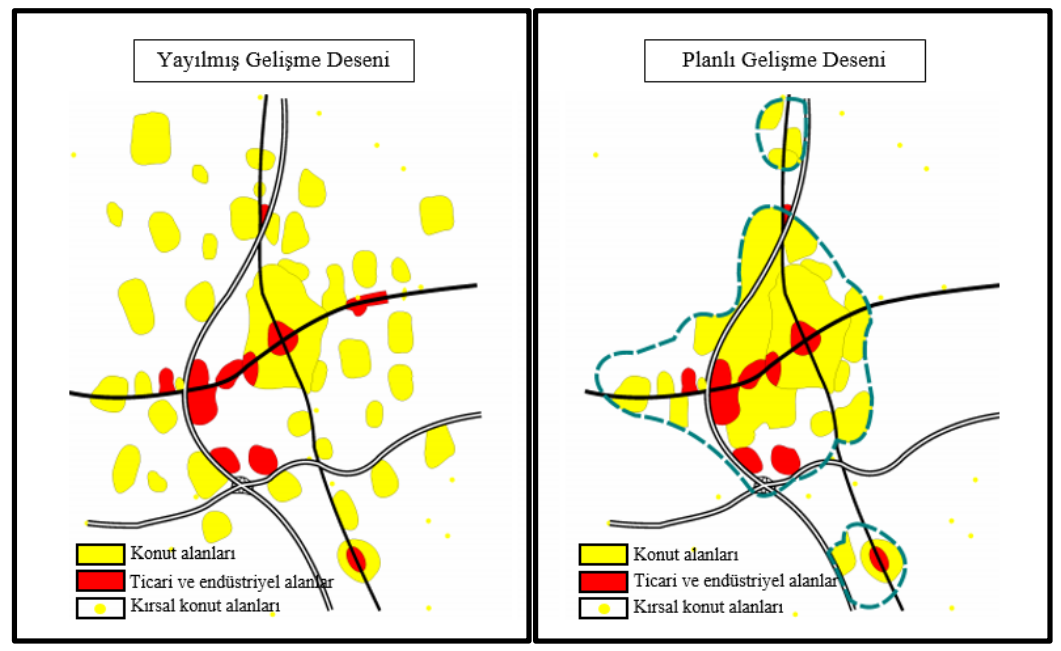

Şekil 1. Aynı nüfusa ve farklı kentsel gelişim desenine sahip iki yerleşimin gösterimi (The Virginia Chapter of the American Planning Association, 2000, s.4) 


\section{Kentsel Yayılmanın Nedenleri}

Kentsel yayılma her coğrafyada farklı sebeplerle gerçekleşmekle birlikte, sanayileşme sonrası yaşanan kent problemlerinin tetikleyici olduğunu öne sürmek mümkündür. Avrupa kentlerinde konut alanlarının düzensiz gelişimi, altyapının yetersiz oluşu, sanayi kaynaklı çevre kirliliği, kötü kent koşullarının beraberinde getirdiği salgın hastalıklar ve artan suç oranları kentlerin yayılmasına hız kazandırmıştır (Büyükcivelek, 2017, s.87). Gerek metro ve tramvay gibi ulaşım araçlarının kentle buluşması gerekse kent merkezindeki problemlerden uzaklaşmak isteyen orta ve üst sınıfların çeperlerde yer seçmesi ile RUF bölgelerinin oluştuğu ve böylelikle Avrupa'da kentsel yayılmadan söz edilir olduğu görülmektedir. ABD'de ise İkinci Dünya Savaşı'ndan sonra kentsel yayılma ivme kazanmıştır. Savaş sonrası ani doğum oranı artışı konut talebine neden olmuş ve konut edinimindeki sübvansiyonlar, yeni ulaşım ağlarının oluşturulması ve otomobilin gündelik yaşamın parçası olması kentlerin çeperlere doğru genişlemesine katkı sağlamıştır. Böylece bireyler bir yandan kentin imkânlarından faydalanırken, diğer yandan kentsel yeşil alanlara yakın yaşama olanağı edinebilmişlerdir (Putnam, 2000, s.224). Bu anlamda ABD'deki banliyöleşme hareketinin bir sonuç ürünü olan düşük yoğunluklu gelişmenin modern yaşam biçimleriyle alakalı olduğu ileri sürülebilir (Staley, 1999, s.3).

Bir tür kentsel büyüme formu olarak görülen kentsel yayılmayı planlı büyümeden ayıran karakteristikler söz konusu olduğunda araştırmacıların yaklaşımları farklılık göstermektedir (Bhatta, 2010, s.9). Mieszkowski ve Mills (1993), nüfus ve gelirdeki artış ile işyeri-konut arası geliş gidiş maliyetlerindeki azalmanın talep üzerinde etkili olduğunu ve bu talep değişiminin kentsel yayılmaya zemin hazırladığını öne sürmektedir (Mieszkowski ve Mills, 1993, s.144). Ewing (1997)'e göre kentsel yayılmanın dört ana nedeni bireysel tüketim tercihleri, teknolojik yenilikler, devlet yardımları ve kamuya ait şirketler ile kamu yararına çalışan şirketlerdir (Ewing, 1997, s.111-112). Brueckner vd. (2001)'ne göre ise nüfus ve gelirdeki artış, vergi oranı, ulaşım ve altyapı hizmetlerinin gelişmesi ile işyeri-konut arasındaki ilişki kentsel yayılmaya neden olmaktadır (Brueckner, Mills, ve Kremer, 2001, s.67).

Nüfus artışı, gelir artışı, arsa spekülasyonu, ulaşım olanaklarının artışı ve merkezi-yerel yönetim politikaları literatürde kontrolsüz genişlemenin başlıca belirleyicileri olarak ön plana çkmakta olup, bu bölümde kentsel yayılmanın nedenleri bu beş faktör üzerinden tartışılmıştır. 


\section{Nüfus artışı}

Kentlerde istihdam olanaklarının artması ve sosyal-teknik altyapı hizmetlerinin sunulması nüfus artışının temel gerekçesini oluşturmaktadır. Sermaye birikim mekânı olmaları da kentleri çekici yapan unsurlardandır. Bunların yanı sıra savaş veya afet gibi nedenlerle ulusal veya uluslararası düzeyde yer değiştiren bireyler de ulusların politikalarına bağlı olarak kent nüfusuna dahil olabilmektedir. Doğal nüfus artışıla kente katılan bireylerin konut ihtiyacı uzun vadede ortaya çıkmakla beraber, göç ile kent yaşamına katılanların başta mesken amaçlı olmak üzere mekân taleplerine çabuk karşlık vermek gerekebilmektedir (Brueckner vd., 2001, s.65). Bu bağlamda her türlü nüfus artışı ek mekân talebine neden olmakta, özellikle nüfusu halihazırda yoğun olan bölgeler yoğunluklarını korumakta zorlanmaktadır (Fulton, Pendall, Nguyễn, ve Harrison, 2001, s.10). Nüfustaki artışa karşılık yeterli miktarda arazi ayrılmadığı durumda kent planlananın dışında ve hazırlıksız olarak gelişmektedir. Genellikle sıçrayarak ve düşük yoğunluklu olarak gerçekleşen bu gelişme yerel yönetimler için mali yükü, kent sakinleri içinse yaşam kalitesi düşük yapılı çevreyi beraberinde getirmektedir.

\section{Gelir artışı}

Ekonomik gelişim gayrimenkul talebini olumlu yönde etkilediğinden, maddi olanakları iyileşen hanelerin konut tercihindeki değişiklikler kentsel yayılmayı tetikleyen temel unsurlar arasında gösterilmektedir (Brueckner vd., 2001, s.69). Geliri artan hanelerin zaman geniş açık alanlı ve/veya sosyal tesisleri mevcut geniş konutlarda yaşama eğilimi, nüfustan bağımsız olarak ekonomik iyileşmeyi başlı başına kentsel yayılmanın belirleyicilerinden biri yapmaktadır. Kent merkezlerinin niteliksiz oluşu veya köhnemesi de bireylerin yaşam kalitesini artırmaya yönelik yeni konut arayışı içine girmelerine neden olabilmektedir. Bu işleyiş aynı zamanda gelir düzeyiyle ilişkili bir mekânsal ayrışmaya da yol açmaktadır (Mieszkowski ve Mills, 1993, s.136).

\section{Arsa spekülasyonu}

Kentsel yayılmanın başlıca aktörlerinden biri geliştirme yapmak için uygun koşulları bekleyerek arsayı elinde tutan ve spekülasyona neden olan yatırımcılardır (Var, Aliefendioğlu, Canaz, ve Tanrıvermiş, 2017, s.3). Spekülatif beklentilerle piyasadan mahrum edilen arsalar zamana yaygın olarak geliştirildiğinde kentin sıçramalı olarak büyümesi kaçınılmaz olmaktadır (Gemeda, Girma-Abebe ve Eckardt, 2019, s.7). Arsa spekülasyonundan elde edilen değer artış kazançlarında kamu yararı bulunmamakta (Karataş, 2007, s.4), yanı sıra bu arsaların elde tutulması arzı sınırladığından arsa değerlerinde suni 
artış gerçekleşmekte ve RUF arsa piyasasında oturmuş bir arsa değerinden söz etmek mümkün olamamaktadır (Ottensmann, 1977, s.391).

\section{Ulaşım olanaklarının artışı}

Son yarım yüzyılda ulaşım olanaklarının artmasıyla birlikte kent merkezi ve çeper arasındaki seyahat süresi kısalmış ve çalışma mekânının kent merkezinde seçilmesi durumunda dahi bireylerin merkezden uzakta yaşamaları mümkün hale gelmiştir (Lewyn, 2000, s.318). Kent merkezine kolay erişilebilirliği sağlayan karayollarına yatırım yapılması merkez ve saçak arasındaki etkileşimi artırmış ve akabinde desantralize gelişen ticari birimler ortaya çıkmıştır (Glaeser ve Kahn, 2003, s.3). Buna ek olarak araç sahipliğindeki artış bireylerin hareketlilik özgürlüğü elde etmesini sağlayarak kentsel yayılma alanlarındaki konut tercihine etki etmiştir (Gillham, 2002, s.70). Avrupa Birliği üyesi ve aday ülkeleri kapsayan bir araştırma bunu destekler şekilde araç sahipliğindeki artışın kent merkezindeki nüfus yoğunluğunu azalttığını ortaya koymaktadır (Patacchini ve Zenou, 2009, s.145).

\section{Merkezi-yerel yönetim politikalan}

Dünyada kamu sübvansiyonlarının yayılmayı yönetsel anlamda teşvik edebildiği veya engelleyebildiği bilinen bir gerçektir. ABD'de yapılan bir araştırma ulaşım sübvansiyonlarının potansiyel olarak mekânsal büyümeyi tetiklediğini ve vergi yükünü artırdığını öne sürmektedir (Brueckner, 2005, s.716). Almanya için yapılan bir araştırma ulaşım sübvansiyonları ve düşürülen benzin vergilerinin kentsel yayılmaya katkı sağladığını; buna karşın toplu taşımayı sübvanse etmenin refahı artırdığını ortaya koymaktadır (Tscharaktschiew ve Hirte, 2012, s.298-300). Benzer şekilde Portekiz'de toplu taşıma sübvansiyonlarının mekânsal etkiye sahip olduğu ve kent merkezinde yaşayan hane sayısını artırdığı saptanmıştır (Mendonça vd., 2020, s.10). Parçacı planlarla izole yerleşmeler oluşturulması kadar planlama politikalarının ve planlara dayanak oluşturan yasal düzenlemelerin yetersizliği de istemsizce kentsel yayılmayı teşvik edebilmektedir (Bhatta, 2010, s.26).

\section{Kentsel Yayılmanın Etkileri}

Kentlerde düzensiz büyümenin bir problem olarak görülmesi, kırsal alanların ihtiyacı aşan ölçüde kentsel alana dönüştürülmesinin bir sonucudur. İnsan eliyle yapılmış bu köklü değişim hem doğal çevre ve finansal kaynakların hızla tükenmesine neden olmakta hem de sosyal adaleti ve yerel yönetimlerin hizmet sunumundaki ekonomik verimliliği etkilemektedir (Soule, 2006, 
s.5; Terzi ve Bölen, 2010, s.168). Zira kentsel arazi kullanım dokusu, kamusal hizmetlerin sunum maliyeti ile yakın ilişki içindedir. Keleş (2015), kentsel hizmetin dağınık ve geniş alana yaygın kent bölgelerinde sunulmasını pahalı bir girişim olarak görmektedir (Keleş, 2015, s.55). İspanya' da kentsel yayılmanın belediye giderleri üzerindeki etkilerinin incelendiği çalışmada kentsel yayılma alanları için gerçekleşen kişi başı harcamaların kent merkezlerine göre daha yüksek olduğu saptanmıştır (Benito, Bastida, ve Guillamon, 2010, s.261). Kompakt kent ile karşılaştırıldığında, düşük yoğunlukla gelişen bir kent daha yüksek teknik ve sosyal altyapı maliyeti gerektirmektedir. Genel bir ifade ile yerleşim yerlerinin nüfus yoğunluğu arttığında altyapının kişi başı inşa ve bakım maliyeti düşmektedir.

ABD'de yapılan bir araştırma kentsel yayılma alanlarında yol inşa maliyetinin \%25 ila \%33 arasında, doğalgaz, atık toplama ve elektrik gibi kamu hizmetlerinin sunum maliyetinin ise \%18 ila \%25 arasında arttığın tespit etmiştir (Cuomo, 1999, s.21). Başka bir araştırmada sıçramalı bir biçimde kent merkezi dışında gelişen yerleşim alanlarına altyapı sağlamanın kent merkezindeki yerleşim alanlarına oranla \%40 daha maliyetli olduğu görülmüştür (McGuire ve Sjoquist, 2003, s.15). Burada maliyet artısının yanı sıra hizmet verimliliğindeki düşüşün de dikkate alınması önem taşır (Keleş, 2015, s.56). Sözgelimi, toplu ulaşım hizmetinde taşıma mesafesinin artmasına karşılık taşınan kişi sayısının azalması verimli hizmet sunumunu engellemektedir. Türkiye'de yapılan bir araştırma yerleşim yoğunluğu azaldıkça metro, otobüs ve hafif raylı sistem benzeri toplu taşıma sistemlerinde verimliliğin azaldığını ve toplumsal maliyetin arttı̆ını ortaya koymaktadır (Acar, 2007, s.30). Ancak her yerleşimin kendi mekânsal dinamikleri içinde değerlendirilmesi gerektiğinin de altı çizilmelidir. Örneğin bir araştırma, saçaklanan yapı gösterdiği tespit edilen İstanbul İli Beykoz İlçesi'nin kamusal hizmet sunumu bakımından literatürde sözü edilen olumsuzluklarla karşılaşmadığını ortaya çıkarmıştır (Özügül ve İnal-Çekiç, 2015, s.69).

Çeperlere toplu ulaşımın yetersiz olması veya toplu taşıma ile yolculuk sürelerinin genellikle uzun zaman alması kişileri özel araç kullanımına yöneltebilmektedir. Özel araç kullanımındaki büyüyen talep ise enerjinin etkin kullanılmayışının yanı sıra emisyon salımını artırarak hava kirliliğine de neden olmakta ve kentsel yayılmanın yan etkisi olarak tartışma konusu edilmektedir (Frumkin, 2002, s.202). Bununla beraber kentsel yayılma ve hava kirliliği arasında doğrudan bir ilişki kurulamayacağını savunan araştırmalar da vardır. Örneğin Cho ve Choi (2014) kentlerde emisyon kaynaklarının 
mekânsal yoğunluğu sonucunda hava kirliliğinin arttığını, kompakt gelişimin hava kirliliğinin azalmasına katkıda bulunmadığını, ancak yeşil alan oranının artmasına fayda sağladığını savunmaktadır (Cho ve Choi, 2014, s.5979). Benzer olarak Chen, Jia ve Lau (2008) kompakt kentsel gelişimin çevresel karakteristikler üzerinde beklenen düzeyde anlamlı bir etkisi olmadığı sonucuna varmışlardır (Chen, Jia, ve Lau, 2008, s.38-39).

Yayılarak büyümenin verimli tarım alanlarına baskısı ise çevresel boyutta ele alınması gereken ayrı bir konudur. Dünyada 1965 yılında kişi başı ekilebilir arazi alanı 0,351 hektar olurken, bu alan 1990 yılında 0,237 ve 2015 y1lında 0,194 hektara düşmüştür (World Bank, 2016). Öte yandan dünya nüfusu 1965-1990 yılları arasında \%59, 1990-2015 yılları arasında ise \%39 artmış, ekilebilir alan azalırken gıdaya olan ihtiyaç artmıştır (World Bank, 2019). Ekilebilir arazilerdeki azalmanın en önemli nedenlerinden biri, söz konusu arazilerin kentsel kullanıma tahsis edilerek statüsünün değiştirilmesidir. Kentsel alandan elde edilen rantın tarım alanlarından elde edilen ranta kıyasla daha yüksek olması verimli tarım arazilerinin kentsel kullanımlara ayrılmasına neden olmakta ve ihtiyacı aşan düzeyde arazi ve doğal kaynak tüketilmektedir (Sezgin ve Varol, 2012, s.275). Bu bağlamda konut ve ticari amaçlı kullanımların kent merkezinden uzaklaşmasının tarım alanı ve orman benzeri açık alanların azalmasına neden olduğu ileri sürülebilir. Ayrıca kentlerin kontrolsüz genişlemesiyle birlikte yerleşimler ve altyapı gittikçe daha geniş yüzeyleri kapattığından yayılarak büyüme özellikle kent merkezinde sel riskini artrrmaktadır (Berndtsson vd., 2019, s.47).

Düşük yoğunluklu yerleşimler yüksek yoğunluklu yerleşimlere göre daha az kültürel firsat ve çeşitlilik sunmaktadır (Burchell vd., 1997, s.73; Soule, 2006, s.5). Çeşitliliğin az olmasında kuşkusuz kentsel yayılma alanlarındaki sosyal ayrışmanın rolü büyüktür. Sosyal ayrışma bazen Türkiye metropollerinde görüldüğü gibi kentin çeperlerindeki ekonomik açıdan avantajlı ve daha fazla seçeneğe sahip kesimin kentten izole, korunaklı yerleşmelerde, sınırlandırılmış alanlarda yaşamasıyla ilgilidir; bazen de kent çeperlerindeki ekonomik ve/veya irksal yoğunlaşmaların bir sonucudur (Özkan-Töre ve Kozaman-Som, 2009, s.122; Soule, 2006, s.7; Yenigül ve Cihangir-Çamur, 2013, s.200). Ayrışmada dezavantajlı gruplar söz konusuysa artan suç oranı ve işsizlik gibi sosyal refahı düşüren unsurlar da yoğunlaşabilmektedir (Burchell vd., 1997, s.91). 


\section{Kentsel Yayılmanın Kontrol Edilmesine Yönelik Mevcut Yaklaşımlar}

Kentte mekânsal gelişimin sınırlandırılmasına yönelik uygulamalar yayılmayı kontrol etme, kentsel büyümeyi şekillendirme ve hassas açık alanları koruma amacı taşımaktadır (Han vd., 2017, s.1). Kentsel sınırlandırma için yaygın olarak kullanılan araçlar yeşil kuşak, kentsel büyüme sınırı ve kentsel hizmet alanıdır (Dawkins ve Nelson, 2002, s.1; Han vd., 2017, s.1). Bunun yanı sıra sürdürülebilir kentsel büyüme için kullanılan toplu taşıma odaklı gelişim (TOD) stratejisi de karma arazi kullanımını alternatif ulaşım çözümleri ile birleştiren mekânsal bir yaklaşımdır (Goodwill ve Hendricks, 2002, s.7).

Ebenezer Howard'ın 19'uncu yüzyılda geliştirdiği bahçe kent modeli yeşil kuşakların temelini oluşturmaktadır. Model ilk olarak 1903 yılında İngiltere, Letchworth'te pratiğe geçirilmiş; on yıl gibi kısa bir zaman sonra dünyanın pek çok ülkesinde kabul gören bir fikir haline gelmiştir (Schuyler, 2002, s.7; Ward, 2002, s.28). Howard'ın kent ve kırın avantajlarını birleştiren bahçe kent kurgusunda yeşil kuşaklar, yerleşimlerin nüfus büyüklügünü sınırlama maksadı taşımaktadır. Benzer şekilde bugün İngiltere' de tasarlanan yeşil kuşak alanlarının öncelikli amacı kentlerin kontrolsüzce yayılmasının önlenmesi, kırsal alanların istila edilmesinin önüne geçilmesi ve komşu yerleşmelerin iç içe geçmesinin engellenmesidir (United Kingdom Ministry of Housing, Communities and Local Government, 2019, s.40).

Arazinin edinimi, işlevinin belirlenmesi, bakımı ve iyileştirilmesi için gereken maliyet, kentsel büyümenin yeşil kuşak ile sınırlandırılmasını elverişsiz hale getirmektedir. Dolayısıyla söz konusu mali yükün hangi finansal araçlarla karşılanacağının önceden planlanması önemli bir husustur. Açık alanları kamulaştırarak kentsel gelişimi sınırlandırmak ya da vergilendirme ve fonlama gibi yenilikçi finansman yaklaşımlarıyla kaynak sağlamak uygulanan bazı yöntemler arasında gösterilebilir. Örneğin Almanya'da bu tür yeşil kuşak projelerine kaynak temin etmek üzere yeşil hisse senedi uygulaması gerçekleştirilmiştir. Bu uygulama kapsamında 65 Euro karşllı̆ında bireyler yeşil kuşağın sembolik bir paydaşı yapılmakta ve toplantılar, rehberli geziler gibi etkinliklere katılma olanağı sağlanmaktadır (Terry, Ullrich, ve Riecken, 2006, s.51).

Bir diğer yaklaşım olan kentsel büyüme sınırı, arazi kullanımını kayda değer biçimde değiştiren yeşil kuşaktan oldukça farklıdır. Kentsel büyüme sınırında kentsel ve kırsal alan bir sinırla ayrılmakta olup, bu büyüme kontrol mekanizmasının mekân üzerindeki etkisi nispeten daha düşüktür (Pendall, Martin, ve Fulton, 2002, s.4). Büyüme sınırının saptanabilmesi için öncelikle 
olabildiğince hassas bir şekilde nüfus projeksiyonlarının yapılması ve ardından gelecek 15-20 yılı kapsayacak şekilde arazi kullanım kararları alınması gerekmektedir. Sınır saptandıktan sonra kentsel büyümeyi yönlendirmek ve sınırlandırmak, kompakt kent gelişimini sağlamak ve gelişime açılacak coğrafi bağlamı ortaya koymak temel amaçlardır (Strauss ve Neamtu, 2006, s.144).

Kentsel büyüme sınırının ABD'de uygulamaları oldukça yaygin olup, Oregon Eyaleti'nde yer alan Portland kenti en bilinen örnektir. 1973 yılında Portland'de büyüme yönetimini içeren mevzuatın onaylanmasıyla kentsel büyüme sınırı girişimi, sınırların planlananın ötesinde birden fazla kez genişletilmesi nedeniyle tam anlamıla başarılı olamamıştır. Öte yandan Portland' de büyüme sınırının belirlenmesinin ardından bitişiğinde yer alan Clark County'de konut arzı hızlı artış göstermiş ve iki yerleşimin uyumsuz ve tutarsız politikaları istenmeyen sonuçlar doğurmuştur (Jun, 2004, s.1336). Bu bağlamda yerel yönetimlerin uyumlu ve eşgüdümlü hareket etmesinin önemi de anlaşılmaktadır.

Kentsel hizmet alanı, sınırlandırma amacı güden politikalar arasında görece daha esnek olanıdır (Pendall vd., 2002, s.5). Yöntemin kentsel büyüme sınırına benzer olduğu bilinmekle beraber, kentsel hizmet alanında kanalizasyon, su temini, arıtma tesisi ve toplu taşıma benzeri kentsel hizmetler saptanan sınırın ötesine gitmemekte, yalnızca sınırın içerisinde geliştirilmesi planlanan yerleşimlere kentsel hizmet götürülmektedir. Hizmetin sunulduğu alan sınırlandırılarak maliyetin düşürüldüğü bir sistem kurgulandığından, gelecek 15-20 yıl için kentsel nüfus projeksiyonları yapılarak, kentsel alan ihtiyacı ve kentsel hizmet sunum maliyeti saptanmaya çalışılmaktadır.

Bir taşıma istasyonu çevresinde tanımlı coğrafi alanda geliştirilen karma arazi kullanımla seyahat süresi ve mesafelerin kısaltılması, otomobil kullanma ihtiyacının azaltılması ve toplu ulaşım olanaklarına kolaylıkla erişilebilmesini hedefleyen transit odaklı gelişim projeleri de kentsel yayılma kaynaklı trafik sıkışıklığının azaltılmasında rol oynamaktadır (Goodwill ve Hendricks, 2002, s.9). ABD, Kanada, Brezilya, Fransa ve Hong Kong'da TOD projeleri, orta ve düşük sosyoekonomik statülü banliyö sakinlerinin ulaşım olanaklarını arttırmak ve kentteki taşıt yükünü azaltmak amacıyla sıklıkla uygulanmaktadır.

Mekânsal gelişimin sınırlandırılmasına ilişkin uygulamaların yanı sıra mali teşvik veya yaptırımları içeren politikalarla da kentsel yayılmayı kontrol altına almak olasıdır. Vergilendirme, kontrollü kentsel büyümeyi sağlayabilmek amacıyla sıklıkla uygulanan araçlardan biri olup, hem iyi bir arazi yönetimi için hem de spekülasyonu engellemek için kullanılmaktadır (Bahl ve 
Martinez-Vazquez, 2007, s.4-5). Yapılan çalışmalardan, kent çeperinde yaşamanın maliyeti vergilendirme ve kente geçiş ücreti gibi finansal yaptırımlarla artırıldığında, bireylerin kent merkezinde yaşamaya yöneldikleri anlaşılmaktadır (Turnbull, 2004, s.235). Buna ilaveten, kentin merkezinde bulunan boş durumdaki arsalardan fazladan vergi alınarak merkezde yeni konut stokunu artırmak ve spekülatif amaçlarla elde tutulan bu boş arsaların neden olduğu emniyetsizliği bertaraf etmek de mümkündür.

Kentsel yayılmanın durdurulmasına ilişkin stratejiler, yayılma olgusunun uzun zamandır kentsel çalışmaların gündemini meşgul ettiğini göstermektedir. Her kentin kendine özgü problemleri ve ihtiyaçları olduğundan kentsel büyümeyi kontrol etmeye ilişkin tek bir çözümden söz etmek de olası değildir. Bazı stratejiler sorunu çözmekte başarılı olurken, bazıları yeni sorunlara neden olabilmektedir. Örneğin mekânsal gelişimin sınırlandırılmasına yönelik uygulamalarda mülkiyet hakkı devreye girdiğinden hak sahipleriyle uzlaşma sorunu ortaya çımaktadır. Kent yetkililerinin mülkiyet hakkı ihtilaflarını gerekçe göstererek harekete geçmemesinin kentlere daha fazla zarar verebileceği düşünüldüğünde, imar hakkı transferi gibi yenilikçi araçların pratikte kullanımı önem kazanmaktadır (Aliefendioğlu ve Duman, 2017, s.165).

Kentsel yayılmanın kontrol edilmesine yönelik tartışılan öneriler halen uygulama alanı bulsa da uzun erimli, genel, esnek olmayan ve kestirimlerden faydalanan büyüme yönetimi müdahaleleri günümüz karmaşık kentlerinin sorunlarına kısmen çözüm sunabilmektedir. Zira mekânsal süreçlere yapılan kısıtlayıc girişimler teknisist planlama anlayışının bir ürünü olarak görülmekte ve günümüz dünyasındaki gerçeklikle örtüşmemektedir (Tekeli, 2009, s.240). Bununla birlikte konut piyasasında arz artırılarak fiyatların dengede tutulduğu göz önüne alındığında, arsa arzının mekânsal büyüme stratejileriyle büyük ölçüde sınırlandırılması konut fiyatlarını spekülatif olarak şişirebilmektedir (Carruthers, 2002, s.1963). Bu bağlamda kentsel büyüme yönetiminde daha esnek ve müdahaleci uygulamalar yerine yönlendirici uygulamaların tercih edilmesi önerilmektedir.

Literatür araştırmaları, kentsel yayılma alanlarındaki konut piyasasına ilişkin göstergeler analiz edilerek kentsel büyüme yönetimine girdi sunulabileceğini ortaya koymuştur (Blumenfeld, 1949, s.54; Karantonis, 2008, s.2; Mieszkowski ve Mills, 1993, s.136). Çalışmanın sonraki bölümünde kentsel yayılma alanındaki konut talebini kent merkezinden farklılaştıran sosyoekonomik ve mekânsal faktörler incelenmekte ve kontrollü kentsel gelişmeye nasıl katkı sağlayabilecekleri tartışılmaktadır. 


\section{Kentsel Yayılma Alanlarında Konut Talebinin İncelenmesi}

Konutun evrensel olarak barınmanın yanı sıra bir yatırım aracı olma işlevi de vardır (G. Hayrullahoğlu, Aliefendioğlu, Tanrıvermiş, ve A. C. Hayrullahoğlu, 2018, s.1; Tanrıvermiş, 2016, s.297). Bu bağlamda en düşük standartlara sahip konut ile hanelerin ödeme gücü üzerinden satın aldıkları konut arasında bireylerin ekonomik durumlanı, varlıkları ve beklentileriyle orantılı olarak belirgin bir fark bulunmaktadır. Konut gereksinimi, bir kişi için gereken en küçük birimi ifade ederken, konut talebi hanelerin belirli bir konutun kirasını veya fiyatını ödeme istekliliğidir (Keleş, 2015, s.389). Konut gereksinimi söz konusu olduğunda barınma işlevi gören ekonomik bir mesken, konut talebi söz konusu olduğunda ise hedonik talepler devreye girmektedir. Kent merkezinden çeperlere gidildiğinde gelir durumu, nüfus yoğunluğu, eğitim düzeyi, istihdam, arazi kullanım türleri ve fiziki çevre gibi yerleşim yerlerinin iç yapısını ortaya koyan faktörlerin hedonik isteklere bağlı olarak değişmesi beklenen bir durumdur. Bu nedenle çeperlerdeki talebi ve dolayısıyla piyasa değerini kent merkezinden farklılaştıran sosyoekonomik ve mekânsal gösterge değişimlerinin araştırılması ve yorumlanması kentsel büyüme eğilimlerini anlaşılır kılmaktadır.

Konut talebi özellikle sosyoekonomik yapı değişiminden büyük ölçüde etkilenmekte; ekonomik büyüme, artan nüfus ve azalan hanehalkı büyüklüğü konuta olan talebi yükseltmektedir. Bunun yanı sıra bireylerin eğitimi, farklı kuşakların sosyal normları, kültürel değerler ve medeni durum da konut tercihini etkileyen unsurlar arasındadır (Lin, Allan, ve Cui, 2015, s.250). Yaygın görüşe göre geliri artan bireyler, ekonomik ve sosyal sınıflarına uygun bireylerle aynı semtte yaşamayı tercih etmektedir (Leung ve Tsang, 2012, s.323). Yaş, oda sayısı, alansal büyüklük, kalite, sosyal imkânlar ve otopark sayısı gibi yapısal karakteristikler ise konut tercihinin öteki boyutunu oluşturmaktadır. Esasen konut piyasasında tüm bu hedonik isteklerin bir arada karşılanması mümkün olmadığından, özellikle üst gelir grubunun talep ve eğilimlerine uygun konut üretimi için çeperlerdeki boş arsalar cazip bir seçenektir (Aksoylu, 2015, s.416; Hu, Chulasai, ve Phuangsaichai, 2011, s.162). Nitekim, dünyadaki pek çok metropoliten kentte piyasa güçleri, üst gelir grubunun neoliberalizmle başlayan prestijli, konforlu ve güvenli konut arayışına cevaben sermayeyi kent çeperlerine aktararak talebe uygun konut arzı gerçekleştirmiştir. Bu durumda piyasa güçlerinin işleyişi, özellikle nüfus artış hızı yüksekse, sınırsız ve sıçramalı bir kentsel gelişimi teşvik etmekte ve hassas alanların kentsel baskıya maruz kalması kaçınılmaz olmaktadır (Razin, 
1998, s.337). Bu hızlı dönüşüm, fiziksel yapıyı iyileştirmekle sorumlu kurumları zor durumda bırakmanın yanı sıra kentsel gelişimin piyasa güçlerinden bağımsız düşünülemeyeceğini de göstermektedir.

Kentin merkezinde konumlu fakat merkezle bütünleşemeyen bölgeler ve kullanım dışı kalan endüstri alanları gibi güvenli olmayan mekânlar sosyal statüsü artan haneleri çeperlerdeki daha nitelikli ve çevre kalitesi yüksek konut alanlarına yöneltebilmektedir (Aliefendioğlu ve Tanrıvermiş, 2015, s.738). Cowell (2011)'in ABD'de 2000 yılına ait veriyi kullanarak gerçekleştirdiği çalışma, maddi olanakları çeperlerdeki yeni gelişme alanlarında yaşamaya yetebilen hanelerin zaman içinde kent merkezini düşük gelir grubuna bıraktığını ve bu gelir eşitsizliğinin kent merkezindeki suç oranlarını artırdığını göstermektedir (Cowell, 2011, s.16). Suç oranlarının artması ise yaşam tarzını koruma güdüsü taşıyan daha çok sayıda haneyi kent merkezinden itmekte ve sosyal kutuplaşma giderek daha da derinleşmektedir.

Buna karşın ABD kentlerinde, merkezdeki yüksek konut maliyetleri nedeniyle banliyölerdeki daha düşük fiyatlı konutlarda yaşamanın tercih edildiği de bilinen bir gerçektir (Burchell vd., 1997, s.88). Gayrimenkul değerlerinin kent çekirdeğine yaklaşıldıkça yüksek oluşu merkezde yaşamanın maliyetini artırmakta, başta işe geliş gidişler olmak üzere kent içi yolculukların kolaylaşması RUF bölgelerine erişilebilirliği kolaylaştırmakta ve arsa değerlerinin görece düşük olduğu çeperleri çekici hale getirmektedir. Konut talebini artıran bu dinamik, kentsel yayılma alanlarında doğal artış hızının üzerinde bir nüfus artısına neden olmaktadır (Yenigül ve Cihangir-Çamur, 2013, s.228).

Sosyoekonomik sınıf farklılıklarının yanı sıra farklı kuşakların çağın gerekliliklerine göre değişen tercihleri de konut talebi üzerinde etkili olmaktadır. Kentsel gelişim kararları alınmadan önce gelecekteki kullanıcılar hakkında yeterli bilgi edinilmediğinde kullanıcılar tatminsizlik nedeniyle yeni yaşam alanları arayışına girebilmektedir. Günümüzde iletişim teknolojilerinin ilerlemesiyle özellikle $Y$ ve $Z$ kuşağı için kent merkezine yakın olmanın önemi giderek ortadan kalkmıştır. Benzer şekilde $Y$ kuşağının konut talebini anlamaya yönelik yapılan çalışmalar, müstakil konutlarda ve kent yaşamının olanaklarına sahip çeper bölgelerde yaşama isteklerinin baskın olduğunu göstermektedir (Kayapınar-Kaya, Özdemir, ve Dal, 2019, s.728; Logan, 2014, s.27).

Kent içindeki yolculuklar çoğunlukla konut referans alınarak gerçekleştirilen günlük seyahatlerden kaynaklandığ için konut tercihiyle doğrudan ilişkilidir. Son yarım yüzyılda değişen kent formları kent içi yolculuk talebini de değiştirmiş ve kentin çekirdeğinde ikamet etmenin önemini ortadan kaldırmıştır. 1980'lerde merkezi iş alanı dışında gelişen işgücünün alt merkezler 
oluşturması, nüfusun mekânsal dağılımını açıklamada tek merkezli kent modelinin işlevsel olmadığı tartışmalarını beraberinde getirmiştir. Çok-merkezli kent modeli konut ve işyerlerinin alt merkezlerde dengelendiği bir yapıya sahip olduğundan, kent içi ulaşım süresini ve mesafesini azaltmakta ve kentsel yayılmanın azalmasına katkı sunmaktadır (Gordon, Richardson, ve Jun, 1991, s.419; Varol, Sat, Gürel-Üçer ve Yenigül, 2017, s.73). Bununla beraber hane içindeki her bir bireyin işyeri-konut mesafesini optimize etmek mümkün olamayacağından, çeper ve merkez dışı odakları kapsayacak şekilde seyahat etme olasılığı, bireylerin kent içi hareketliliklerinin anlaşılmasını tek merkezli bir kent modeline kıyasla karmaşık hale getirmektedir.

Kent içi hareketliliği kolaylaştıran toplu taşıma ve ulaşım altyapısı benzeri olanakların artışı, kent merkezi ve çeperi arasındaki ilişkiyi güçlendirmektedir. Ancak yoğunluğu düşük RUF bölgelerine sunulan toplu taşıma hizmeti tam kapasite yürütülemediğinden ulaşımın maliyet etkinliği tartışma konusudur. Sosyoekonomik açıdan avantajlı hanelerde otomobil sahipliğinin artması çeper ve merkez arası yolculukların süresini düşürmektedir. $\mathrm{Bu}$, aynı zamanda hane bireylerinin kentten uzak yaşamayı göze alıp çeperlere yerleşmelerinin başlıca nedenleri arasında gösterilmektedir. Hollanda'da yapılan bir araştırmada da işyeri ve konut mesafesi ile ekonomik statü ve eğitim düzeyi arasında pozitif yönlü bir bağıntı saptanmıştır (Schwanen, Dieleman, ve Dieleman, 2001, s.184).

Mekânsal dinamiklerin kentsel yayılma alanlarında kent merkezine k1yasla farklı olması, diğer bir ifadeyle hem tarım arazisi hem de arsa özelliğinin bir arada yer alması, bu alanlardaki konut ve arsa karakteristiklerini de farklılaştırmaktadır (Ö. Karakayacı ve Z. Karakayacı, 2012, s.114). Gayrimenkul piyasalarında arazi kullanımdaki olası bir değişikliğe verilen yanıt uzun zaman alabilmektedir. Piyasada konut talebinde bir artış olduğu varsayıldığında, uygun arazinin temin edilmesi, hukuki ve mali koşulların yerine getirilmesi gibi pek çok husus nedeniyle arzda gecikme yaşanması olasıdır. Arazinin arsa vasfı kazanma süreci zaman aldığından, yaşanan bu gecikmeler RUF bölgelerinde konut piyasasının talep yönlü tepkilere geç yanıt vermesi ile sonuçlanmaktadır (Mayer ve Somerville, 2000, s.87). Bu bağlamda kent merkezindeki konut piyasasının çeperlere nazaran olgun olduğu sonucuna varmak mümkündür. İlaveten kent merkezlerinde gayrimenkul alım satımlarının daha sık olması, gayrimenkullerin nakde çevrilebilirliğini ve sermayeye kazandırılma hızını artırmaktadır. 
Kent merkeziyle kıyaslandığında RUF bölgelerindeki arsa büyüklüklerinin optimal boyutların üzerinde olduğu dikkati çekmektedir. Parsellerin geniş oluşu kır-kent saçağı karakteristiğinin bir yansıması olmakla beraber, kentlerde barınmanın ötesinde imkanlar sunulabilmesi için de elverişli bir ortam sağlamaktadır.

Piyasa güçlerinin mekânsal dağılıma etkisini özellikle konut üzerinden ölçmek mümkündür. Dolayısıyla talep tahmini söz konusu olduğunda konutun fiyatı, emlak vergisi ve kira bedeli gibi göstergelerin bağımlı değişken olarak tercih edilmesi anlamlıdır. Kentsel yayılma alanlarında konut talebinin yapısal olarak nasıl değiştiğini anlayabilmek için literatürde sıkça tercih edilen bağımsız değişkenleri konutun tipi (müstakil, apartman dairesi vs.), alanı, oda sayısı, banyo sayısı, yaşı, otopark adedi, yer aldığı parselin yüzölçümü ve sahip olduğu sosyal imkânlar olarak sıralamak mümkündür (Alkadi, 1996, s.75; Gluszak ve Marona, 2011, s.7, Ottensmann, Payton, ve Man, 2008, s.22). Mevcut eğilimler doğrultusunda farklı mekânsal gelişim bölgelerindeki talep değişimlerini ölçmek içinse her bir değişkenin talep üzerindeki etkisini ortaya çkaran hedonik modellerden faydalanılması önerilmektedir.

\section{Tartışma ve Sonuç}

Kentler 1980 yılı sonrasında neoliberal politikaların etkisiyle sermaye birikim mekânları haline gelmişlerdir. Akabinde çağdaş iletişim teknolojileri mekânsal yakınlığı önemsiz kılmıştır. Hizmete dayalı sektörlerin çeşitlenmesiyle ticaretin tek bir merkezde yoğunlaşmadığı ve düzensiz olduğu bir kent gelişimi gözlenmeye başlamıştır. Ekonomik dinamiklerin değişmesi, yeni yaşam tarzlarının ve yeni sosyal sınıfların ortaya çıkmasını sağlamış, özel sektörün konut üretmeye başlamasıyla görece sosyoekonomik olarak iyi durumdaki bireylerin farklılaşan konut istemini karşılama odaklı yatırımlar yapılan yeni bir döneme girilmiştir.

Fiyatı arz ve talep etkileşiminin belirlediği gayrimenkul piyasalarında arzın temel bileşenlerinden birini bireylerin beklentileri oluşturmaktadır. Nitekim konut piyasası kısa zamanda çağdaş toplumun değer, beklenti ve tüketim kalıplarına hitap etmeye yönelmiş ve RUF bölgelerinde çoğunlukla varlıklı kesimlerin tercih ettiği yeni konut alanları oluşturularak kentsel yayılma teşvik edilmiştir.

Günümüzde kentlerdeki mekânsal büyüme kontrol edilmediği takdirde hava kirliliği, tarım alanlarının tahrip edilmesi, ekolojik çeşitliliğin azalması, ulaşım maliyetlerinin artması, kent merkezlerinin çöküşü ve sosyo-mekânsal ayrışma gibi birden fazla disiplini ilgilendiren pek çok kent probleminin son 
bulması mümkün görünmemektedir. Bu bağlamda istenmeyen mekânsal büyüme biçimi olarak kabul edilen kentsel yayılmanın ortaya çıkış süreci ve bu makroform değişiminin etkilerini incelemek, kontrollü bir kentsel büyüme için kritik önemdedir.

Kentsel yayılmanın önlenmesi için dünyada kabul gören pek çok pratik olsa da bu uygulamalar büyük çaplı, radikal değişiklikler yapılmaksızın gerçekleştirilememektedir. Ortodoks veya her politik yapıyla uyumlu olmayan yaklaşımlar yerine kente özgü ve alt ölçekli incelemelerle mekânın karakteristiklerine uygun çözümlerin tartışılması gerektiği açıktır. Günümüzde zorlayıcı mekânsal kısıtlamalarla kentsel büyümeyi kontrol etmek yerine, kentsel yayılma alanlarındaki konut talebinin irdelenmesiyle ve/veya uygun kamu sübvansiyonlarıla büyümeyi yönlendirme yaklaşımı ilgi görmektedir. Bu bağlamda gayrimenkul piyasasının işleyişiyle tutarlı varsayımlara dayanan bir kentsel gelişim, mekânsal anlamda yapılabilecek gerçekçi düzenlemelerden biri olacaktır. Talebe uygun konut alanlarının kent merkezine yakın bölgelerde kurgulandığı planlama stratejileri oluşturmanın mümkün olduğu bu yönlendirici yaklaşım, talep değişimleri izlenerek planlama sürecindeki tıkanıklıklara daha hızlı müdahale edebilmeye ve planlara ön etkin yaklaşımla yön verebilmeye olanak tanımaktadır. Bu anlamda mekânsal planların kontrollü bir kentsel gelişimde etkili bir araç olabilmesi için özellikle konut piyasasına yönelik varsayımların dikkate alınması önerilmektedir. Ancak bu süreçte kentsel yayılmanın piyasa talebinin bir yansıması olarak algılanması yerine öncelikle doğal, ekolojik ve ekonomik kaynaklar için bir tehdit olarak görülmesi gerektiği de vurgulanmalıdır. 


\section{Extended Abstract}

\section{A Qualitative Research on Urban Sprawl Areas and Housing Demand in These Areas}

\author{
Gizem Hayrullahoğlu \\ ORCID: 0000-0002-3867-193X
}

\author{
Yeşim Aliefendioğlu Tanrıvermiş \\ ORCID: 0000-0002-0859-7150
}

\author{
Harun Tanrivermiş \\ ORCID: 0000-0002-0765-5347
}

In the last decade, the number of highly urbanized countries has increased considerably. Cities expand in the absence of an area suited for over-population as the urban population grows, necessitating the development of additional zones. This phenomenon, conceptualized as urban sprawl, is widely regarded as one of the most discussed urban challenges of the 21st century, as it has numerous negative implications on long-term development (Martine et al., 2008, p.2). The decentralized extension of the city beyond a pre-planned limit is known as urban sprawl, and it is characterized by poorly managed and decentralized urban development (Blumendfeld, 1949, p.62).

Although urban sprawl was sparked by the rise in capital accumulation prior to World War II, the increase accelerated post-war (Christiansen and Loftsgarden, 2011, p.4; Gonzalez, 2009, p.42). The variety of transportation technologies in cities, in particular, has enhanced the interaction between the urban core and the urban periphery while also separating living space and economic activities. Over time, growth in population and economy, land values in the periphery, increased transportation opportunities, and government policies have further encouraged urban sprawl, which ultimately leads to increased public and private capital costs, high transportation and travel expenses, destroyed land and natural life, poor quality of life, and social segregation. Many inter-disciplinary urban issues such as air pollution, destruction of agricultural land, reduced ecological diversity, higher transportation costs, 
urban decline, and socio-spatial segregation are intimately associated with controlling urban growth. Examining the emergence of urban sprawl and analyzing the implications of the change in urban form associated to urban sprawl are crucial in this respect.

Instruments to solve this issue generally aim to control sprawl, shape urban growth patterns, and protect sensitive open spaces (Han et al., 2017, p.1). The green belt, urban growth boundaries, and urban service boundaries are tools commonly used for urban containment (Dawkins and Nelson, 2002, p.1; Han et al., 2017, p.1). Furthermore, the transport-oriented development strategy to provide sustainable urban growth is another controlling tool that combines mixed land use with alternative transportation solutions (Goodwill and Hendricks, 2002, p.7). These applications are still in use; however, long-term, general, and inflexible growth management interventions can offer partial solutions to the problems of complex cities today.

Urban centers have driving forces, as well as offer many opportunities. Concordantly, to achieve ordered urban growth, the attractive forces of sprawl areas and the driving forces of urban cores must be considered together. The housing market, which allows understanding the internal structure of the settlements, is one of the main tools to explain these driving forces (Blumenfeld, 1949, p.54; Karantonis, 2008, p.2; Mieszkowski and Mills, 1993, p.136). Since the expectations of consumers constitute one of the basic components of supply in real estate markets, examining the housing demand structure allows us to understand the urban sprawl and to make contribution to planning policies. For instance, inner-city residents may move away from urban cores if they cannot meet their expectations (Ewing, 1997, p.111). One of the causes which apply to the low class is that costs such as land value and property taxes are low in the urban fringe. Opting for the upper-middle class is the new and qualified residentials constructed in the sprawling areas. The housing market tends to address the values, expectations, and consumption patterns of contemporary society. The actors in the real estate market adjust their investment strategies as well to changing housing demand. Therefore, indicators of the housing market in urban sprawl areas must be considered in order to ensure ordered urban growth.

Since the factors affecting the housing demand change based on proximity to the urban core, understanding the housing demand differences between the urban fringe and the core becomes critical, according to international and national literature. Socioeconomic structure, generational gap, and travel time -describing urban mobility and accessibility- need to be discussed to 
achieve this. Changes in socioeconomic structure have a significant impact on housing demand; economic growth, increased population, and shrinking household size all rise demand. Furthermore, educational background, generational social norms, cultural values, and marital status are among the factors that influence resident choice (Lin, Allan, and Cui, 2015, p.250). There is also a strong relationship between intra-urban travel trends and urban form. Intra-urban mobility varies greatly depending on the commuting time and distance. Housing preferences also have an impact on transportation modes and offering a sustainable transportation in sprawl areas where automobiledependent transportation is common becomes an uphill struggle.

Although there are many accepted strategies for preventing urban sprawl, it is hard to implement them without major and dramatic changes. It is selfevident that space-dependent solutions should be discussed instead of orthodox approaches. In recent years, rather than controlling urban growth with spatial constraints, the focus has shifted to guiding housing demand and/or providing appropriate public subsidies. One of the realistic arrangements that can be created to manage disorganized urban growth is urban development based on assumptions consistent with the forces of the real estate market. Bottlenecks in the planning process can be intervened in more rapidly by monitoring demand changes, and city plans can be regulated with a proactive approach using this guiding strategy. In this sense, we recommend considering the assumptions about the real estate market so that spatial plans can be an effective tool in a controlled urban development. However, in this process, urban sprawl should not be perceived as a reflection of market demand, but rather as a threat to natural, ecological, and economic resources.

\section{Kaynakça/References}

Acar, İ. H. (2007). Trafik ve ulaşım konularında kanılar ve gerçekler. Yedinci Ulaştırma Kongresi Bildiriler Kitabı (ss. 23-34) içinde. İstanbul, Türkiye: TMMOB İnşaat Mühendisleri Odası.

Aksoylu, S. (2015). Development of the urban periphery and issues related to urban landscape due to gated communities. Journalism and Mass Communication, 5, 415-427.

Aliefendioğlu, Y. ve Duman, İ. (2017). İmar hakları transferinde değer esaslı uygulama olanakları: Van ili örneği. Akademik Sosyal Araştırmalar Dergisi, 5(49), 163-193.

Aliefendioğlu, Y. ve Tanrıvermiş, H. (2015). Kentsel dönüşüm sürecinde taşınmaz ve proje değerleme işlemleri ve sorunlarının analizi: Kayseri Büyükşehir 
Belediyesi Sahabiye ve Fatih Mahalleleri Dönüşüm Projesi örneği çerçevesinde değerlendirme. Uluslararası Sosyal Araştırmalar Dergisi, 8(39), 736-769.

Alkadi, A. (1996). Hedonic analysis of housing prices near the Portland urban growth boundary, 1978-1990. (Yayımlanmamış doktora tezi). Portland State University, Portland, ABD.

Bahl, R. ve Martinez-Vazquez, J. (2007). The property tax in developing countries: Current practice and prospects. Cambridge, ABD: Lincoln Institute of Land Policy.

Benito, B., Bastida, F. ve Guillamon, M.D. (2010). Urban sprawl and the cost of public services: An evaluation of Spanish local governments. Journal of Local Self-Government, 8(3), 245-264.

Berndtsson, R., Becker, P., Persson, A., Aspegren, H., Haghighatafshar, S., Jönsson, K., ... ve Tussupova, K. (2019). Drivers of changing urban flood risk: a framework for action. Journal of Environmental Management, 240, 47-56.

Bhatta, B. (2010). Analysis of urban growth and sprawl from remote sensing data. Berlin, Almanya: Springer Science and Business Media.

Blumenfeld, H. (1949). On the growth of metropolitan areas. Social Forces, 28, 5964.

Brueckner, J. K. Mills, E. ve Kremer, M. (2001). Urban sprawl: Lessons from urban economics. Gale, W. G. ve Pack-Rothenberg, J. (Der.), Brookings-Wharton papers on urban affairs içinde (ss. 65-97). Washington DC, ABD: Brookings Institution Press.

Brueckner, J. K. (2005). Transport subsidies, system choice, and urban sprawl. Regional Science and Urban Economics, 35(6), 715-733.

Burchell, R. W., Downs, A., Seskin, S., Moore, T., Listokin, D., Davis, J. S., Shad, N. A., Helton, D., Gall, M. ve Phillips, H. (1997). The costs of sprawl-revisited: The evidence of sprawl's negative and positive impacts. Washington DC, ABD: Transportation Research Board National Research Council.

Buttenheim, H. S. ve Cornick, P. H. (1938). Land reserves for American cities. The Journal of Land and Public Utility Economics, 14, 254-265.

Büyükcivelek, A. B. (2017). Tarih içinde kent. Özdemir, S. S., Özdemir-Sarı, Ö., ve Uzun, N. (Der.), Kent planlama içinde (ss. 69-93). Ankara: İmge Kitabevi.

Carruthers, J. I. (2002). The impacts of state growth management programmes: A comparative analysis. Urban Studies, 39(11), 1959-1982.

Chen, H., Jia, B. ve Lau, S. S. Y. (2008). Sustainable urban form for Chinese compact cities: Challenges of a rapid urbanized economy. Habitat International, 32(1), 2840.

Cho, H. S. ve Choi, M. J. (2014). Effects of compact urban development on air pollution: Empirical evidence from Korea. Sustainability, 6(9), 5968-5982.

Christiansen, P. ve Loftsgarden, T. (2011). Drivers behind urban sprawl in Europe (1136/2011). Norwegian Centre for Transport Research, Institute of Transport Economics. 1 Ekim 2019 tarihinde https://www.toi.no/getfile.php/1317329- 
1303822159/Publikasjoner/TØI\%20rapporter/2011/1136-2011/1136-2011-el.pdf adresinden erişildi.

Cowell, C. N. (2011). Influencing factors behind urban sprawl in the United States. (Yayımlanmamış üstün başarı programı tezi). University of Northern Iowa, Iowa, ABD.

Cuomo, A. (1999, Haziran). The state of the cities third annual report. Washington DC, ABD: Department of Housing and Urban Development The Secretary. 12 Ocak 2018 tarihinde https://www.huduser.gov/publications/pdf/soc99.pdf adresinden erişildi.

Davidson, M. ve Dolnick, F. (2004). A planners dictionary (No. 521/522). 12 Aralık 2017 tarihinde https://www.planning.org/publications/report/9026853/ adresinden erişildi.

Dawkins, C. J. ve Nelson, A. C. (2002). Urban containment policies and housing prices: An international comparison with implications for future research. Land Use Policy, 19(1), 1-12.

Delibay, A. S. (2014). Kentsel büyüme yönetimi ve mega projeler: İstanbul 3. Havalimanı etkileşimde Göktürk yerleşmesi örneği (Yayımlanmamış yüksek lisans tezi). Bahçeşehir Üniversitesi, İstanbul.

Ewing, R. (1997). Is Los Angeles style sprawl desirable?. Journal of the American Planning Association, 63(1), 107-127.

Frumkin, H. (2002). Urban sprawl and public health. Public Health Reports, 117, 201-217.

Fulton, W. B., Pendall, R., Nguyễn, M. ve Harrison, A. (2001). Who sprawls most?: How growth patterns differ across the US. Washington, DC, ABD: Brookings Institution Center on Urban and Metropolitan Policy.

Gemeda, B. S., Girma-Abebe, B. ve Eckardt, F. (2019). Urban land speculation; failure of land market. Survey Review, 53(376), 1-7.

Gillham, O. (2002). The limitless city: A primer on the urban sprawl debate. Washington DC, ABD: Island Press.

Glaeser, E. L. ve Kahn, M. E. (2003). Sprawl and urban growth. Henderson, V ve Thisse, J. F. (Der.), Handbook of regional and urban economics (4. bs.) içinde (ss. 2481-2527). Amsterdam, Hollanda: Elsevier.

Gluszak, M. ve Marona, B. (2011, Temmuz). Housing demand, urban sprawl and gated societies: Evidence from Poland. European Network for Housing Research Konferansinda sunulan bildiri, Toulouse, Fransa.

Gonzalez, G. A. (2009). Urban sprawl, global warming, and the empire of capital. New York, ABD: State University of New York Press.

Goodwill, J. ve Hendricks, S. J. (2002). Building transit oriented development in established communities. Florida, ABD: University of South Florida Center for Urban Transportation Research. 
Gordon, P., Richardson, H. W. ve Jun, M. J. (1991). The commuting paradox evidence from the top twenty. Journal of the American Planning Association, 57(4), 416-420.

Han, H., Huang, C., Ahn, K. H., Shu, X., Lin, L. ve Qiu, D. (2017). The effects of greenbelt policies on land development: Evidence from the deregulation of the greenbelt in the Seoul metropolitan area. Sustainability, 9(1259), 1-17. doi:10.3390/su9071259.

Harvey, R. O. ve Clark, W. A. V. (1965). The nature and economics of urban sprawl. Land Economics, 41(1), 1-9.

Hayrullahoğlu, G., Aliefendioğlu, Y., Tanrıvermiş, H. ve Hayrullahoğlu A. C. (2018). Estimation of the hedonic valuation model in housing markets: The case of Çukurambar region in Çankaya district of Ankara province. Ecoforum Journal, 7(1), 1-9.

Hu, X., Chulasai, L. ve Phuangsaichai, S. (2011). Hedonic pricing model for housing market in city of Kunming, the People's Republic of China. Chiang Mai University Journal of Economics, 15(1), 144-165.

Jun, M. J. (2004). The effects of Portland's urban growth boundary on urban development patterns and commuting. Urban Studies, 41(7), 1333-1348.

Kanbak, A. (2013). İstanbul ve kentsel saçaklanma. MSGSÜ Sosyal Bilimler Dergisi, 8, 11-30.

Karakayacı, Ö. ve Karakayacı, Z. (2012). Kentsel saçaklanma alanlarında arsa/arazi değerini belirlemeye yönelik yöntem önerisi. International Journal of Social Science, 5(4), 107-120.

Karantonis, A. C. (2008, Ocak). Population growth and housing affordability in the modern city-Sydney a case study. Pacific Rim Real Estate Society Konferansinda sunulan bildiri, Kuala Lumpur, Malezya.

Karataş, N. (2007). İzmir'deki şehirsel saçaklanma eğilimlerinin TorbalıAyrancılar'da arazi sahipliliği el değişim süreçlerine etkileri. TMMOB Şehir Planciları Odası Planlama Dergisi, 2, 3-10.

Kayapınar-Kaya, S., Ozdemir, Y. ve Dal, M. (2019). Home-buying behaviour model of generation Y in Turkey. International Journal of Housing Markets and Analysis, 13(5), 713-736.

Keleş, R. (2015). Kentleşme politikası (14. bs.). Ankara: İmge Yayınevi.

Leung, T. C. ve Tsang, K. P. (2012). Love thy neighbor: Income distribution and housing preferences. Journal of Housing Economics, 21(4), 322-335.

Lewyn, M. E. (2000). Suburban sprawl: Not just an environmental issue. Marq. Law Review, 84(301), 301-382.

Li, J., Qiu, R., Li, K. ve Xu, W. (2018). Informal land development on the urban fringe. Sustainability, 10(1), 1-17.

Lin, D., Allan, A. ve Cui, J. (2015). The impacts of urban spatial structure and socioeconomic factors on patterns of commuting: A review. International Journal of Urban Sciences, 19(2), 238-255. 
Logan, G. (2014, 29 Eylül). The millenial generation's influence on real estate demand. ULI Capital Markets Konferansında sunulan bildiri, Güney Karolina, ABD.

Martine, G., McGranahan, G., Montgomery, M. ve Fernandez-Castilla, R. (2008). The new global frontier: Urbanization, poverty and environment in the 21st century. Londra, Birleşik Krallık: Earthscan.

Mayer, C. J. ve Somerville, C. T. (2000). Residential construction: Using the urban growth model to estimate housing supply. Journal of Urban Economics, 48(1), 85-109.

McGuire, T. J. ve Sjoquist, D. L. (2003). Urban sprawl and the finances of state and local governments. David J. Sjoquist (Der.), State and local finances under pressure, studies in fiscal federalism and state-local finance içinde (ss. 299-326). Cheltenham: Edward Elgar Publishing.

Mendonça, R., Roebeling, P., Martins, F., Fidélis, T., Teotónio, C., Alves, H. ve Rocha, J. (2020). Assessing economic instruments to steer urban residential sprawl, using a hedonic pricing simulation modelling approach. Land Use Policy, 92, 104458.

Mieszkowski, P. ve Mills, E. S. (1993). The causes of metropolitan suburbanization. Journal of Economic Perspectives, 7(3), 135-147.

Ottensmann, J. R. (1977). Urban sprawl, land values and the density of development. Land Economics, 53(4), 389-400.

Ottensmann, J. R., Payton, S. ve Man, J. (2008). Urban location and housing prices within a hedonic model. Journal of Regional Analysis and Policy, 38(1), 19-35.

Özkan-Töre, E. ve Kozaman-Som, S. (2009). Sosyo-mekânsal ayrışmada korunaklı konut yerleşmeleri: İstanbul örneği. Megaron Yıldız Teknik Üniversitesi Mimarlık Fakültesi E-Dergisi, 4(3), 121-130.

Özügül, D. ve İnal-Çekiç, T. (2015). Kentsel saçaklanmayı yerel kentsel hizmetlere erişim perspektifinden okumak; Beykoz üzerine bir çözümleme. Mimarist, 15(54), 65-70.

Patacchini, E. ve Zenou. (2009). Urban sprawl in Europe. Burtless, G. ve PackRothenberg, J. (Der.), Brookings-Wharton papers on urban affairs içinde (ss. 125149). Washington DC, ABD: Brookings Institution Press.

Pendall, R., Martin, J. ve Fulton, W. (2002, Ağustos). Holding the line: Urban containment in the United States. Washington DC, ABD: Brookings Institution Center on Urban and Metropolitan Policy. 12 Kasım 2018 tarihinde https://www.brookings.edu/wpcontent/uploads/2016/06/pendallfultoncontainment.pdf adresinden erişildi.

Putnam, R. D. (2000). Bowling alone: The collapse and revival of American community. New York, ABD: Simon and Schuster.

Razin, E. (1998). Policies to control urban sprawl: Planning regulations or changes in the 'rules of the game'?. Urban Studies, 35(2), 321-340. 
Schuyler, D. (2002). Introduction. Parsons, K. C., ve Schuyler, D. (Der.), From garden city to green city: The legacy of Ebenezer Howard içinde (ss. 1-13). Baltimore, Maryland, ABD: The Johns Hopkins University Press.

Schwanen, T., Dieleman, F. M. ve Dijst, M. (2001). Travel behaviour in Dutch monocentric and policentric urban systems. Journal of Transport Geography, 9(3), 173-186.

Scott, A. J., Carter, C., Reed, M. R., Larkham, P., Adams, D., Morton, N., ... Coles., R. (2013). Disintegrated development at the rural-urban fringe: Re-connecting spatial planning theory and practice. Progress in Planning, 83, 1-52.

Sezgin, D. ve Varol, Ç. (2012). Ankara'daki Kentsel Büyüme ve Saçaklanmanın Verimli Tarım Topraklarının Amaç Dışı Kullanımına Etkisi. METU JFA, 29(1), 273-288.

Soule, D. C. (2006). Defining and Managing Sprawl. Soule, D. C. (Der.), Urban sprawl: A comprehensive reference guide içinde (ss. 3-11). Westport, USA: Greenwood Press.

Staley, S. (1999). The sprawling of America: In defense of the dynamic city. Los Angeles, ABD: Reason Foundation. 12 Aralık 2018 tarihinde https://reason.org/wpcontent/uploads/files/ed09db5e026808f5a16e1e56cf28aad3.pdf adresinden erişildi.

Strauss, E. J. ve Neamtu, B. (2006). Policy tools for addressing urban sprawl: Urban growth boundaries. Transylvanian Review of Administrative Sciences, 2(16), 136153.

Tanrıvermiş, H. (2016). Gayrimenkul değerleme esasları. Ankara: Sermaye Piyasası Lisanslama Sicil ve Eğitim Kuruluşu A.Ş. (SPL).

Tekeli, İ. (2009). Akılcı planlamadan, bir demokrasi projesi olarak planlamaya. İstanbul: Tarih Vakfı Yurt Yayınları.

Terry, A., Ullrich, K. ve Riecken, U. (2006). The green belt of Europe: From vision to reality. Gland, İsviçre ve Cambridge, Birleşik Krallık: International Union for Conservation of Nature and Natural Resources.

Terzi, F. ve Bölen, F. (2010). İstanbul'da şehirsel saçaklanmanın ölçülmesi. İTü Dergisi/A Mimarlik, Planlama, Tasarım, 9(2), 166-178.

The Virginia Chapter of the American Planning Association. (2000). Patterns of suburban growth. 4 Aralı 2017 tarihinde http://www.gwrcftp.org/Regional_Planning/Planning_Reference_Docs/Patter ns_of_Suburban_Growth.pdf adresinden erişildi.

Travisi, C. M. ve Camagni, R. (2005). Sustainability of urban sprawl: Environmentaleconomic indicators for the analysis of mobility impact in Italy. 10 May1s 2017 tarihinde https://papers.ssrn.com/sol3/papers.cfm?abstract_id=812788 adresinden erişildi.

Tscharaktschiew, S. ve Hirte, G. (2012). Should subsidies to urban passenger transport be increased? A spatial CGE analysis for a German metropolitan area. Transportation Research Part A: Policy and Practice, 46(2), 285-309. 
Turnbull, G. K. (2004). Urban growth controls: Transitional dynamics of development fees and growth boundaries. Journal of Urban Economics, 55(2), 215-237.

United Kingdom Ministry of Housing, Communities and Local Government. (2019). National planning policy framework. 22 Aralık 2020 tarihinde https://assets.publishing.service.gov.uk/government/uploads/system/upload s/attachment_data/file/810197/NPPF_Feb_2019_revised.pdf adresinden erişildi.

UN: Department of Economic and Social Affairs, Population Division. (2019). World urbanization prospects: The 2018 revision (ST/ESA/SER.A/420). New York, ABD: United Nations.

Var, G., Aliefendioğlu, Y., Canaz, S. ve Tanrıvermiş, H. (2017, 20-24 Mart). Transformation of land to land lot, value gain, land speculation, and opportunities for sharing value increment: An evaluation of the Turkey example. World Bank Land and Poverty Konferansinda sunulan bildiri, Washington DC, ABD.

Varol, Ç., Sat, N. A., Gürel-Üçer, Z. A. ve Yenigül, S. B. (2017). Metropoliten alanlarda çok-merkezli mekânsal gelişmelerin sürdürülebilirlik üzerinden değerlendirilmesi: Avrupa Birliği'ndeki uygulamalar. TÜBAV Bilim Dergisi, 10(1), 61-74.

Ward, S. V. (2002). Ebenezer Howard, his life and times. Parsons, K. C., ve Schuyler, D. (Der.), From garden city to green city: The legacy of Ebenezer Howard içinde (ss. 14-37). Baltimore, Maryland, ABD: The Johns Hopkins University Press.

World Bank. (2016). Arable land (hectares per person). 14 Ocak 2018 tarihinde https://data.worldbank.org/indicator/AG.LND.ARBL.HA.PC adresinden erişildi.

World Bank. (2019). Population, total. 5 Ekim 2020 tarihinde https://data.worldbank.org/indicator/SP.POP.TOTL adresinden erişildi.

Yenigül, S. B. ve Cihangir-Çamur, K. (2013). Saçaklanma dinamiklerinin yerleşimlerin dönüşümüne etkisi: Kirsaldan kentsele Ankara/Pursaklar. İdealkent, 4(9), 198-231. 